\title{
Investment Attractiveness of a Region: Evaluation Practices
}

\author{
Anna Yu. Kosobutskaya ${ }^{1, *}$ Annie V. Ravohanginirina ${ }^{2, a}$ \\ ${ }^{1}$ Voronezh State University, Voronezh, Russia \\ ${ }^{2}$ University of Antananarivo, Ankatso, Antananarivo, Madagascar \\ ${ }^{a}$ E-mail: vohangininie@yahoo.fr \\ *Corresponding author.Email: anna.rodnina@mail.ru
}

\begin{abstract}
The article discusses the main foreign and domestic practices (techniques) for evaluating a region's investment attractiveness; their heuristic capabilities, features of development and special aspects of use are considered, and their benefits and drawbacks are highlighted. The position of Russian regions in various ratings is shown. The article also identifies the main "consumers" of the results of evaluating regional investment attractiveness.
\end{abstract}

Keywords: investment climate, investment attractiveness, investment risk, investment potential, region, evaluation methods, ranking

\section{INTRODUCTION}

Due to the limitations of regional economic resources and the need for attracting additional investment resources, the efforts of government bodies are aimed at creating conditions for improving the investment attractiveness of regions and their investment climate, ensuring an inflow of investments and spreading the best practices developed in the regions. Timely and correct use of investments ensures the socio-economic development of the region, contributes to the creation of new jobs and, as a consequence, the improvement of the well-being of its population.

The investment attractiveness of a region determines the degree of its competitiveness in the capital, labor and innovation markets. An investor, when making decisions on the direction of investing his funds, analyzes the objective characteristics of the proposed investment object, such as the region's opportunities to attract investments (a set of geographical, socio-economic, political, financial, socio-cultural, organizational, legal and other factors that can attract investors). An investor also analyzes restrictions that impede the implementation of these opportunities, presented by regional investment risks.

In difficult situations, the results of an expert assessment of the investment climate in the region reinforce the investor's experience and intuition. "The clearer and more accessible the information about the opportunities and risks associated with a particular object, the easier it is for an investor to assess its investment attractiveness and make a balanced investment decision" [1]. So today the study and improvement of the tools for assessing a region's investment attractiveness take on a particular importance.

The main "consumers" of the results of assessing the regional investment attractiveness are state authorities (federal and regional), as well as business representatives. The latter help the federal authorities in identifying regions that are lagging behind in terms of subjective factors of investment attractiveness and need to improve the quality of management, as well as in providing additional financial support. Regional authorities see the positions of various regions in the "investment space" of the country, as well as subjects where the best management practices in the investment sphere are applied [2]. In addition, relying on certain integral indicators, the authorities can seek to mitigate the imbalance in the level of socio-economic development of the regions of the Russian Federation (as well as municipalities within the regions) and thereby reduce social tension.

Despite the fact that the methodological support for assessing investment attractiveness in foreign economic literature appeared no more than 30 years ago, today the problem is not in the absence or shortage of appropriate methods (there are many of them), but in their optimal selection for use [3],[4].

In a number of cases, regional investment attractiveness is assessed by one of the most significant indicators or by their limited set, in other cases, the calculation involves dozens of indicators characterizing 
the investment climate and investment attractiveness of the region, or even a larger number of them.

\section{FOREIGN METHODS FOR ASSESSING THE INVESTMENT ATTRACTIVENESS OF A TERRITORY}

Since the mid-1990s, foreign rating agencies have been operating in Russia, assigning ratings to the constituent entities of the Federation. The most famous are the methods of Harvard Business School, the consulting firm A.T. Kearney, and Forbes and Euromoney magazines.

The Harvard Business School methodology focuses on the risks of an investor in a particular region. It assesses such factors as the political situation in a country or a particular region, legal conditions for national and foreign investors, inflation rate, the state of the national currency, the possibility of using national capital, and the possibility of capital export [5]. The rating of regional investment attractiveness is calculated based on expert assessments of the indicated groups of characteristics.

Subsequent techniques imply the expansion and complication of the system of parameters estimated by experts, as well as the introduction of quantitatively measured indicators.

The methodology of the magazine Euromoney includes nine groups of indicators, the values of which are determined by calculation and analytical or expert methods. With their help, the following are assessed: the state of the region's debt, the creditworthiness of the region, the inability to service the debt, the level of political risk, the efficiency of the economy, the availability of bank lending, and the availability of short-term financing and long-term loan capital.

The Forbes magazine methodology contains 15 parameters reflecting various aspects of economic life, which are grouped as follows: economic situation, socio-demographic characteristics, infrastructure, population security, comfort of doing business, and business climate.

To make investment decisions, the Foreign Direct Investments Confidence Index is often used, which is calculated by the A.T. Kearney firm. This rating involves a survey of more than 500 business leaders from around the world (the minimum annual turnover of participating companies is 0.5 billion USD, 42 percent of participating companies with a turnover of more than 1 billion USD). The rating takes into account the most significant parameters for direct investment, such as "quality of regulation and investment protection, the volume of domestic demand, poverty rate, the level of corruption, quality of protection of intellectual property rights, educational level of the population, the rate of growth or decline of bureaucracy, etc." [6].

The Standard \& Poor's rating assesses the issuer's ability to fulfill its debt obligations on time [7]. The highest rating category is "AAA;" the lowest is "D." The results of these assessments reflect the relative level of investment risk in the respective regions and are guidelines for foreign investors.

The Economic Department of the Bank of Austria has prepared an analytical material Regional Risk Rating in Russia, which calculates various assessments of the risks of investing in the regions of the Russian Federation, taking into account their political situations and economic and social statuses. According to the results of the calculation, the results were presented, where all regions were divided into six classes:

- First grade- favorable situation for investing capital.

- Second grade - relatively favorable situation.

- Third grade - a controversial situation.

- Fourth grade - an unfavorable situation.

- Fifth grade - a seriously unfavorable situation.

- Sixth grade - a dangerous situation for investing capital

\section{RUSSIAN METHODS FOR ASSESSING THE INVESTMENT ATTRACTIVENESS OF A TERRITORY}

Since 1997, Russia has been developing its own methods of assessing the investment attractiveness of regions to avoid the pressure of ratings of international agencies and to take into account the national and regional characteristics.

It should be noted that today in Russia there is no unified, transparent legally-approved methodology for assessing regional investment attractiveness (investment climate), which would be simple, clear, understandable and suitable for use by both investors evaluating potential investment objects and those wishing to attract investment resources for assessing their capabilities.

There are many domestic methods for analyzing and assessing the investment attractiveness of regions, which are adapted to Russian socio-economic and informational conditions. Currently, such structures as the Council for the Study of the Productive Forces of the Ministry of Economic Development of the Russian Federation and the Russian Academy of Sciences, and such officially accredited rating agencies in Russia as the National Rating Agency (NRA) and the Expert RA Rating Agency for Strategic Initiatives (RAEX) are 
engaged in the study and assessment of the investment attractiveness of regions. The methods they use are the most well-known, tested and regularly used in drawing up various kinds of investment ratings.

The enlarged existing approaches to assessing the investment attractiveness of regions via calculating indicators can be divided into three groups: economic and mathematical (the method of the sum of places and the method of scoring), factor analysis (compilation of factor models that determine the relationship of features, and regression models, revealing the weight of each factor indicator) and expert assessments.

The developed tools and methods in use for assessing the investment attractiveness of a region depend on the approach to understanding the investment attractiveness. Note that in modern economic science there is no commonly accepted understanding of this concept. Interpretations of investment attractiveness are diverse [for details, see 8], which determines the insufficient development of the methodology for studying the factors and conditions that determine it, while knowledge of the factors allows for pointwise influence on certain components of the investment climate to increase its favorability.

The most widespread approach is the consideration of a region's investment attractiveness as a generalized characteristic of the totality of its economic, social, legal, political, organizational and socio-cultural prerequisites, which predetermine the expediency and attractiveness of investing resources in the economic system of the region. This approach is reflected in the existing methods for assessing regions' investment attractiveness, for example, in the methodology of the Expert RA rating agency, popular in Russia, according to which "the assessment of the investment climate of the region is formed on the basis of data on investment attractiveness (investment potential) and investment risk" [9]. However, many authors consider such a division of factors not obvious [10].

Based on a significant number (about 200) of qualitative and quantitative indicators published by the Federal Service "Rosstat" of the Russian Federation, the Ministry of Finance of the Russian Federation, the Ministry of Economic Development and Trade of the Russian Federation, the Ministry of Regional Development of the Russian Federation, the Ministry of the Russian Federation for Taxes and Levies, the Bank of Russia, and other official authorities, "Expert RA" conducts an annual analytical study "Rating of investment attractiveness of Russian regions". The results of the study are published in the journal Expert.

In accordance with the Expert RA methodology, the value of the investment potential takes into account the indicators affecting the possible volumes of investment in the region, and consists of 9 components (resource and raw materials, labor, production, consumer, infrastructural, innovation, institutional, infrastructural, financial and tourist private potentials), each of which is characterized by a group of indicators. Investment risk reflects the probability of loss of investments and income from them and includes six private types of risk (economic, social, financial, managerial, environmental and criminal).

Assessment of the investment climate of the regions involves the passage of four stages [11]

- 1. Calculation of the share of each region of Russia for all types of investment potential in general indicators for Russia and indices of private types of investment risks in relation to the average all-Russian indicator.

- 2. Calculation of the total investment potential (as the weighted average value by expert weights of the shares of each region for all nine types of private potentials) and the integral investment risk (the weighted average sum of the private investment risks of the region). The assessment of the importance of the contribution of each component to the total potential or integral risk is carried out as a result of an annual survey of Russian and foreign experts and investment companies.

- 3. Ranking of regions in terms of total investment potential or integral investment risk.

- 4. Assigning to each region a rating of investment attractiveness, which determines the ratio of the level of integral investment risk and the value of the total regional investment potential. Each region of Russia belongs to one of 13 rating categories: from "high potential minimal risk" (1A) to "low potential - extreme risk" (3D). The regions where high investment potential is accompanied by minimal or moderate risk are the most attractive for investors. At the time of the last assessment (2017), there were few such regions. These are St. Petersburg, Moscow and the Moscow region, the Krasnodar Territory, the Sverdlovsk Region. The group of regions with medium potential and minimal or moderate risk included eight subjects of the Russian Federation. Most of all regions of the Russian Federation (46) belong to groups with low or insignificant potential and minimal or moderate risk. For example, in 2017, the Voronezh region confirmed its $3 \mathrm{~A} 1$ rating, which means "reduced potential - minimal risk." The most unattractive regions for investors are regions with low potential and extreme risk. These are the Republic of Ingushetia and the Republic of Tuva. 
Per the opinion of a number of researchers, this technique gives the investor results that are informative, although not devoid of some subjectivity.

Another fairly common approach to understanding the investment attractiveness of a region is presented in the methodology of the Council for Studying the Productive Forces of the Ministry of Economic Development of the Russian Federation and the Russian Academy of Sciences, in which the regional economic space is considered in the "investment attractiveness investment activity" coordinate system [12]. This approach focuses on not only factorial, but also performance indicators characterizing the investment attractiveness of the region, which is its significant difference from the approach of the rating agency "Expert RA".

The investment activity of the region is determined based on indicators of the legislative, social, production and financial activities of the region. When assessing the investment attractiveness, the level of investment risk is taken into account by studying unemployment in the region, crime, conflicts in labor relations and other factors. The causal relationship between investment attractiveness and investment activity, the possibility of substantiating the reliability, as well as the accuracy of the assessment results are the undoubted advantages of this technique.
The investment attractiveness of a region, calculated according to the methodology of the National Rating Agency, depends on seven factors: "the provision of the region with natural resources and the quality of the environment in the region, labor resources of the region, regional infrastructure, the internal market of the region (potential of regional demand), production potential of the regional economy, institutional environment and socio-political stability, financial sustainability of the regional budget, and regional enterprises," and involves the use of 55 indicators [13].

The rating assessment of the investment attractiveness of a region is carried out according to a special scale, divided into three categories: regions with high, medium and modest levels of investment attractiveness. There are three levels within each category. As a result, a qualitative characteristic of investment attractiveness is obtained, in which the quantity is given by vague estimates (high, medium, low).

In 2018, the largest number of Russian regions (34 out of 85) was included in the category of "medium investment attractiveness" - in groups IC4, IC5, and IC6 (refer to "Table I"). It should be noted that the number of regions with an average investment attractiveness has decreased in comparison to 2016, which allows us to conclude that regional disparities in the investment context are increasing.

TABLE I. DISTRIBUTION OF RUSSIAN REGIONS BY THE LEVEL OF INVESTMENT ATTRACTIVENESS (ACCORDING TO THE EXPERT RA METHODOLOGY) (END OF 2018)

\begin{tabular}{|c|c|c|}
\hline \multirow{3}{*}{$\begin{array}{l}\text { Regions with a } \\
\text { high level of } \\
\text { investment } \\
\text { attractiveness }\end{array}$} & IC1 group & 2 cities: Moscow, St. Petersburg \\
\hline & IC2 group & $\begin{array}{l}7 \text { regions: Belgorod, Leningrad, Moscow, Sakhalin, and Tyumen Regions; Republic of Tatarstan; } \\
\text { Yamalo-Nenets Autonomous District }\end{array}$ \\
\hline & IC3 group & $\begin{array}{l}15 \text { regions: Voronezh, Kaliningrad, Kaluga, Lipetsk, Magadan, Nizhny Novgorod, Samara, Sverdlovsk, } \\
\text { and Tula Regions; Krasnodar Territory; Republic of Bashkortostan; Republic of Sakha (Yakutia); } \\
\text { Khabarovsk Territory; Khanty-Mansyisk Autonomous District; Nenets Autonomous District }\end{array}$ \\
\hline \multirow{3}{*}{$\begin{array}{l}\text { Regions with an } \\
\text { medium level of } \\
\text { investment } \\
\text { attractiveness }\end{array}$} & IC4 group & $\begin{array}{l}8 \text { regions: Amur, Novosibirsk, Rostov, and Tomsk Regions; Krasnoyarsk Territory; Perm Territory; } \\
\text { Primorsky Territory; Chukotka Autonomous District }\end{array}$ \\
\hline & IC5 group & $\begin{array}{l}11 \text { regions: Vladimir, Vologda, Irkutsk, Kursk, Murmansk, Orenburg, Tambov, Ulyanovsk, } \\
\text { Chelyabinsk, and Yaroslavl Regions; Kamchatka Territory }\end{array}$ \\
\hline & IC6 group & $\begin{array}{l}15 \text { regions: Arkhangelsk, Astrakhan, Volgograd, Novgorod, Omsk, Penza, Ryazan, Saratov, and } \\
\text { Smolensk Regions; Republic of Adygea; Republic of Karelia; Republic of Komi; Stavropol Territory; } \\
\text { Udmurt Republic; Chuvash Republic }\end{array}$ \\
\hline \multirow{3}{*}{$\begin{array}{l}\text { Regions with a } \\
\text { moderate level } \\
\text { of investment } \\
\text { attractiveness }\end{array}$} & IC7 group & $\begin{array}{l}7 \text { regions: Altai Territory, Bryansk, Kemerovo, Kostroma, and Oryol Regions; Republic of Altai; } \\
\text { Republic of Mordovia }\end{array}$ \\
\hline & IC8 group & $\begin{array}{l}8 \text { regions: Sevastopol; Jewish Autonomous Region; Kirov, Pskov, and Tver Regions; Republic of } \\
\text { Buryatia, Republic of Crimea, Republic of Khakassia }\end{array}$ \\
\hline & IC9 group & $\begin{array}{l}12 \text { regions: Trans-Baikal Territory, Ivanovo and Kurgan Regions; Kabardino-Balkar Republic; } \\
\text { Karachay-Cherkessia Republic; Republic of Dagestan; Republic of Ingushetia; Republic of Kalmykia; } \\
\text { Republic of Mari El; Republic of North Ossetia - Alania; Republic of Tuva; Chechen Republic }\end{array}$ \\
\hline
\end{tabular}

The share of 24 regions with high investment attractiveness accounts for $86 \%$ of the total amount of foreign direct investment. At the same time, the 27 regions in the category with the worst investment attractiveness indicators (IC7, IC8, and IC9) account for less than $2 \%$ of foreign direct investment. In almost all regions that are classified as the most unfavorable IC9 level, foreign direct investment is completely absent [14]. 
The methodology of the Agency for Strategic Initiatives determines the national rating of the state of the investment climate in the constituent entities of the Russian Federation. The rating is developed on the basis of surveys of entrepreneurs and experts from the regions, as well as on official statistics. The rating uses 44 indicators, which are grouped in four areas: the regulatory environment, institutions for business, support for small business, infrastructure and resources [15]. Beyond rating, data is additionally collected on 31 more indicators. This is done in order to determine the possibility of their inclusion in the methodology in the future, as well as to identify the best regional practices. The rating is calculated and presented at four levels: the level of indicators (initial data for each indicator, reduced to a single scale from zero - the worst measurement - to 100 - the best); the level of factors (weighted average scores for the indicators included in the factors); the level of directions (weighted average values of the factors included in the direction) and the level of the integral index (the sum of points in all four directions)

Note that the following regions showed the best dynamics in the rating of regions by investment climate in 2020: Yaroslavl, Kaliningrad regions, Republic of Bashkortostan, Krasnodar Territory, and Kaliningrad oblast. The worst negative dynamics were noted in the Tyumen and Tambov regions.

\section{Conclusion}

The ranking results stimulate competition between regions in the struggle for investment. Since 2017, the study covers all regions of Russia. In 2020, the top ten leaders included Moscow, the Republic of Tatarstan, Tula oblast, St. Petersburg, Moscow oblast, Krasnodar oblast, Belgorod oblast, Kaluga oblast, Republic of Bashkortostan, and Yaroslavl oblast [16].

After analyzing the above methods, we can conclude that they differ from each other in methodological approaches, the number of levels in the structure of assessing investment attractiveness, the scale of the set of criteria and particular indicators used, parameters of regional comparisons, methods of collecting and processing information, and presenting the results. The undoubted advantage of these techniques can be considered the ability to track the dynamics of socio-economic and other processes based on the constancy of the criteria used. As the main problems of their use, one can point to the complexity and bulkiness of calculations associated with the use of a large number of indicators, as well as the obscurity of the choice of the proposed indicators. In some cases, the relationship between the indicators used and the results of assessing regional investment attractiveness may be lost [17].
It should be noted that in addition to the above, there are a whole set of other methods for assessing regional investment attractiveness. For example, a number of authors singled out the following as the main ones: rating of constituent entities of the Russian Federation in terms of investment conditions, compiled by the consulting agency Expert-Region; the rating assessment of the investment climate proposed by S.S. Guzner and V.N. Kharitonova; an approach to assessing investment activity in the regions, based on the category of "regional market reaction"; the assessment of the level of the investment climate in the region using development indices, proposed by I.V. Tikhomirova; K. Guseva's methodology "Ranking of the subjects of the Russian Federation according to the degree of favorable investment climate"; the method of I.A. Blank and a number of others who remained beyond the scope of analysis in this article.

\section{References}

[1] Litvinova V.V. Investment attractiveness and investment climate of the region: monograph. Moscow: Financial University, 2013. - $116 \mathrm{p}$

[2] Emelyanov Yu.S., Leonova Yu.Yu. On the indicators of assessing the investment attractiveness of regions of Russia // Management sciences in the modern world. 2016. Vol. 2. No. 2. Pp. 501-506.

[3] Kosobutskaya A.Yu., Ravuanginirina A.V. Investment attractiveness of the region: assessment methods. // VSU Bulletin. 2019. No. 1. Pp. 32-36.

[4] Suglobov A.E., Morozov I.A. Methodological support for assessing the investment attractiveness of the production potential of depressed regions // Bulletin of the Moscow University of the Ministry of Internal Affairs of Russia. 2016. No. 1. Pp. 200-205.

[5] Robert B. Stobaugh. How to Analyze Foreign Investment Climates. Harvard Business Review, September - October 1969.

[6] Kearney Foreign Direct Investment Confidence Index - A.T. Kearney. Available at: https://www.atkearney.com/foreigndirect-investment-confidence-index

[7] Standard \& Poor`s - official website. Available at: http://www.standardandpoors.com

[8] Kosobutskaya A.Yu., Ravuanzhinirina A.V. The main approaches to the definition of the concepts of "investment," "investment attractiveness," and "investment climate of the region" // Management of changes in socio-economic systems. Collection of articles of international scientific and practical conf. Issue 17 / Ed. Yu.I. Treshchevsky, G.V. Golikova. Voronezh: Istoki, 2018. Pp. 92 - 103.

[9] Methodology for compiling a rating of investment attractiveness of Russian regions // Expert RA. Rating agency. Available at: http: / /raexpert.ru/ratings/regions/concept/

[10] Emelyanov Yu.S., Leonova Yu.Yu. On the indicators of assessing the investment attractiveness of regions of Russia // Management sciences in the modern world. 2016. Vol. 2. No. 2. P. 503.

[11] Methodology for compiling a rating of investment attractiveness of Russian regions // Expert RA. Rating agency. Available at: http: / /raexpert.ru/ratings/regions/concept/ 
[12] Yangulbaeva L.Sh. Essence and economic content of the investment attractiveness of the region // Terra Economicus. 2012. No. 3-2. Pp. 143-148.

[13] National rating agency: Rating of investment attractiveness of Russian Federation subjects. 2017. Available at: http://www.ranational.ru/ru/ratings/provinces?type=rating

[14] Economic and statistical analysis of regional socio-economic systems: monograph / under total. ed. Doctor of Economics Yu.I. Treschevsky. Voronezh, Publishing and Printing Center of Voronezh State University, 2018. - 269 p.

[15] National rating of the investment climate in the constituent entities of the Russian Federation. - Agency for Strategic Initiatives. Available at: https://asi.ru/investclimate/rating/

[16] National rating of the investment climate in the constituent entities of the Russian Federation. - Agency for Strategic Initiatives. Available at: https://asi.ru/investclimate/rating/

[17] Kosobutskaya A.Yu., Ravuanginirina A.V. Investment attractiveness of the region: assessment methods. // VSU Bulletin. 2019. No. 1. Pp. 32-36. 